\title{
Influence of instantaneous variation on estimates of coral reef fish populations and communities
}

\author{
T. R. McClanahan ${ }^{1, *}$, N. A. J. Graham ${ }^{2}$, J. Maina ${ }^{3}$, P. Chabanet ${ }^{4}$, J. H. Bruggemann ${ }^{5}$, \\ N. V. C. Polunin ${ }^{2}$ \\ ${ }^{1}$ Wildlife Conservation Society, Marine Programs, Bronx, New York 10460, USA \\ ${ }^{2}$ School of Marine Science \& Technology, University of Newcastle, Newcastle upon Tyne NE1 7RU, UK \\ ${ }^{3}$ Coral Reef Conservation Project, PO Box 99470, Mombasa, Kenya \\ ${ }^{4}$ Institut de Recherche pour le Développement, Nouméa, New Caledonia \\ ${ }^{5}$ Laboratoire d'Ecologie Marine, Université de la Réunion, BP 7151, 97715 St. Denis, La Réunion, France
}

\begin{abstract}
The magnitude of different sources of variation in coral reef fish abundance data needs to be known if temporal changes in population and community data are to be correctly estimated. A particularly important missing component of the variability is the 'instantaneous' change in fish, largely caused by the interaction between fish movement and observer recognition. This variation occurs at a time scale less than that influenced by the focus of previous studies, including time of day, tides, migration, or birth and death processes. Without this measure of variance, estimates of temporal change are confounded. To determine the magnitude of this instantaneous variance, belt-transect visual counts of damselfish, surgeonfish, and parrotfish were conducted during a short interval at midday during neap tides over consecutive days in the calm season and compared to similar samples in 1992 and 2003. Within-site, or our estimate of instantaneous variation, was the greatest source of variability for the whole assemblage and for the surgeonfish/parrotfish group but not for damselfish. Direct between-year comparisons produced estimates of population change over time that were twice as high as those derived by an indirect method where the instantaneous spatial component was subtracted from the total variation. Because the inherent spatial component of variability makes it difficult to detect site change over time, we recommend sampling designs that use random sampling and have greater statistical power to detect change. Furthermore, aggregate metrics, such as numbers of species or density at the family, community, or the functional group, will have greater potential to detect change for sample sizes typical of coral reef studies. Otherwise, when life history traits and species level change are important, high replication will be required.
\end{abstract}

KEY WORDS: Acanthuridae ' Community composition ' Marine protected areas ' Pomacentridae Population variation $\cdot$ Sampling methods $\cdot$ Scaridae

Resale or republication not permitted without written consent of the publisher

\section{INTRODUCTION}

Detecting change in coral reef fish populations and communities is a challenging task because of differences in detectability among species and inherent variability in abundance (Samoilys \& Carlos 2000, Willis 2001, Thompson \& Mapstone 2002, Edgar et al. 2004, Tessier et al. 2005). Variation is caused by shortterm changes associated with deterministic diurnal and tidal movements (Galzin 1987, Thompson \& Map- stone 2002) and birth and death process (Sale \& Dybahl 1975, Williams 1983, Doherty \& Williams 1988, Hixon \& Carr 1997), but also through more stochastic processes such as movements and the difficulty of detecting and counting small, fast-moving, and often cryptic species (Brock 1982, Fowler 1987, LincolnSmith 1988, Greene \& Alevizon 1989, Kulbicki \& Sarramegna 1999). We refer to this as instantaneous variation, as it is caused by an interaction between the observer and fish movement that occurs on a time scale 
less than the behavioral and population processes that are the focus of many scientific field studies. This variability creates difficulties when attempting to detect patterns of change unless the sources of variation and error are quantified (Sale \& Dybahl 1975, Sale \& Douglas 1984, Bohnsack 1983, Sale et al. 1984, Sale \& Steel 1989, Planes et al. 1993, Galzin et al. 1994). Variations arising from differences in sampling method, interobserver differences, and species, density, and siterelated factors are likely to affect conclusions about actual population variability.

Many studies have assessed the magnitude of temporal change in coral reef fish populations and communities in relation to factors such as protection from fishing (Russ \& Alcala 2004, McClanahan \& Graham 2005), impacts of disturbance (Syms \& Jones 2000, Halford et al. 2004, Graham et al. 2006, Wilson et al. 2006), and their interaction (Jones et al. 2004). Problems of accuracy can confound estimates of change, because there are unavoidable constraints on accurate sampling at specific times and locations and spatial variation can confound temporal variation (Stewart-Oaten et al. 1995). Where spatial variation is high, direct comparisons of mean population densities and community composition over time will be inaccurate, and this is the case for many coral reef organisms (McClanahan 1998, Thompson \& Mapstone 2002).

Mobile species are likely to be more challenging in this regard because of their mobility and related behaviors, such as aggregation, and due to movements related to diurnal, tidal, and seasonal drivers. Although variation may be expected to be less for more sedentary taxa, direct estimation of population differences over time may still be difficult by direct comparisons of means because spatial variation, often associated with social or habitat aggregations, can be large and constitutes an important confounding effect (Stewart-Oaten et al. 1995). For these reasons, estimates of population change actually require an indirect method, where the temporal variation is derived from the difference between the total and other sources of variation (Stewart-Oaten et al. 1995).

It is clearly important to have accurate estimates of instantaneous and other sources of variation when attempting to estimate population variability and to design studies that estimate and minimize these sources of variation to the extent that this is possible. Yet, apart from a notable study (Thompson \& Mapstone 2002), previous studies have scarcely attempted to systematically partition the main sources of error. Estimates of variation in populations over time scales of a single day and tidal cycle test for variation at this scale without distinguishing this variation from background or instantaneous variability (Galzin et al. 1994, Thompson \& Mapstone 2002, Willis et al. 2006). These studies only seldom find significant patterns, perhaps because instantaneous variation is larger than the daily or tidal variation they are trying to detect. One notable exception is a study of reef fishes on Heron Island where variation over time was found, in most cases, to not differ from random walk predictions (Ault \& Johnson 1998). When randomness and instantaneous change are accounted for, it is likely that the magnitude of temporal change will be reduced and become more predictable, varying among species and assemblages in relation to various life-history characteristics and fluctuations in recruitment, growth, and longevity and, thus, speed of population turnover, all of which can be related to body size (Ebeling et al. 1990, Rahel 1990, Jennings et al. 1999).

In this study, the sources of variation in observers, space, and time were examined for a variety of coral reef fish that are common in Kenya and differ in ecological and life-history characteristics related to body size, diet, population density, and movement. Species and community structure in 2 areas subjected to different levels of management (1 closed to fishing for $14 \mathrm{yr}$, the other heavily fished) were compared, which created a natural experimental manipulation of population density for target species and allowed us to determine the effect of reduced abundance on variance. We aimed to compare 2 different ways of estimating temporal variation and determine the sampling effort required to detect levels of change.

\section{MATERIALS AND METHODS}

Study sites. The study was conducted on the lagoonal side of the fringing reefs north of Mombasa, Kenya, in a heavily populated and urbanized area where a marine park and reserve were created in 1989 to reduce fishing. Study areas were subject to different levels of management. The first area was the Mombasa Marine National Park (MMNP), which has been effectively enforced as a strict no-fishing zone since 1991. The second area, located off Ras Iwatine (RAS) $\sim 3 \mathrm{~km}$ from the southern boundary of the MMNP, was part of a marine reserve where most fishing activities (excluding beach seining) were allowed and where fishing intensity was high (McClanahan \& Mangi 2001). Data from 1992, 2003, and 2004 are presented. We expected the MMNP to show signs of recovering from fishing, while RAS was not expected to exhibit such characteristics (McClanahan \& Arthur 2001, McClanahan \& Graham 2005).

The study areas were located on the shallow reef flat ( $<3 \mathrm{~m}$ depth at low tide), where benthic communities form a mosaic of algae and coral-dominated hard substratum, interspersed with patches of sea grass. Ben- 
thic community structure differed between the study sites. Cover of living corals was higher in the MMNP than at RAS $(23.6 \pm 9.7 \%$ and $5.5 \pm 3.6 \%$, respectively, mean $\pm \mathrm{SD}$ ) while that of frondose macroalgae showed the opposite pattern (MMNP $1.7 \pm 1.3 \%$; RAS $22.5 \pm$ $9.0 \%$; Cros \& McClanahan 2003).

Fish censuses. In each area, 3 transect lines of $100 \mathrm{~m}$ length were installed. Fish censuses were carried out by snorkeling along the transect line and counting the number of individual fish by species (Lieske \& Myers 1994) within $2.5 \mathrm{~m}$ of either side (area $100 \times 5 \mathrm{~m}=$ $500 \mathrm{~m}^{2}$ ). Fish were sampled in 3 families by discrete group sampling (DGS), whereby the Pomacentridae were sampled separately from the Acanthuridae and Scaridae (McClanahan 1994). The $500 \mathrm{~m}^{2}$ belt was chosen, as this is close to the area where community variability stabilizes when comparing quadrats of different sizes (T. McClanahan, unpubl. data), and it is a commonly used belt area in this system (McClanahan 1994). Fish $<3 \mathrm{~cm}$ in length were not counted, as their small size and cryptic behavior decreases their detection and increases variability in counts (Fowler 1987). Transects were located in permanently marked locations. In 1 case, the transect line broke (Site 5), and, although we attempted to replace it as closely as possible to the original location, it may have moved (see 'Results').

We undertook a sampling program that was expected to reduce the number of possible variables influencing the fish populations, such that we measured the instantaneous within-site (transect) variability as closely as possible. Consequently, the surveys were conducted by experienced observers, during 1 season at the calmest time of year, on days with calm and sunny conditions and during midday neap tides. These factors have been hypothesized to influence survey results (Helfman 1986, Galzin 1987, Thompson \& Mapstone 2002, Williams et al. 2006); therefore, methods and sampling design were specifically developed to minimize these potential effects. From 2 to 7 December 2004, fish censuses were conducted independently by 5 different observers (TRM, NAJG, PC, JHB, and NVCP), each observer completing 3 census passes of each transect. In most cases, consecutive passes of a transect were completed serially with only a few minutes between transects, such that the time between samples was approximately the time required to complete a transect (approximately $20 \mathrm{~min}$ ). Thus, each transect was surveyed 15 times, 45 passes of transects were made per management area, and 90 passes were made in total during 2004 (Table 1). Identical censuses were carried out during October to December 1992 and February to May 2003 by TRM in 4 sites within each area.

Multivariate representation. Non-metric multidimensional scaling (MDS) was used to describe pat- terns in fish community data for each transect among the 5 observers in 2004 and between the years 1992 and 2003 using the PRIMER-E v6 package (Clark \& Warwick 2001). Data were square-root transformed to down-weight abundant species, and MDS plots were produced based on Bray-Curtis similarity matrices. Group-average cluster analysis was performed on the same similarity matrix, and slices through the cluster dendograms at similarity levels of 50 and 60 were overlaid on the MDS plots to define patterns more clearly (Clark \& Warwick 2001). Data were analyzed in this way at the level of the whole assemblage and at that of taxonomic groups, namely the more sedentary pomacentrids and the more mobile scarids and acanthurids. Unexpectedly, no scarids or acanthurids were seen for 2 passes and only 1 Acanthurus dussumieri was observed in another pass at the RAS study site during 2003; these data were therefore removed due to very low similarity (5-9\%) to the other data. Consequently, it should be remembered that the variation in this group, year, and site is even greater than presented for visual purposes.

Spatial variation. We analyzed the 2004 fish population data from both areas for 4 components of variation and similarity; total, within transect, between transect, and between observer (Table 1). For each area, we calculated the population density and community similarities (based on Bray-Curtis) for 3 levels; each observer within transects ( $\mathrm{n}=45$ paired comparisons, 5 observers $\times 3$ transects $\times 3$ passes), between transects $(\mathrm{n}=$ 15,5 observers $\times 3$ passes), and between observers $(\mathrm{n}=$ 9,3 transects $\times 3$ passes; Table 1 ). The mean and standard deviation of the respective components were calculated, and 1-way ANOVAs were performed to compare RAS and the MMNP. Due to problems meeting the assumptions of a continuous model, we ran an ordinal MANOVA with sites nested within management areas to determine the strength of the factors of observer, site, and management areas on estimates of the population density of the studied species.

We calculated variability based on the coefficients of variation $(\mathrm{CV})$ of each species, within each transect, area, and both areas combined (Table 1). The total CV of the areas was calculated as the means and standard deviations of all passes in the area $(n=45)$. The within-transect $\mathrm{CV}$ compared individual passes in a transect, the between-transect $\mathrm{CV}$ compared the means of all passes within each transect and compared this to the means in the different sites, and the observer CV used the means of the 3 passes of the observer and compared observers using the means of the 3 transects ( $n=9$; Table 1 ).

In order to determine the levels of variation and utility of permanent transects versus random or haphazardly selected transects, we also calculated the CV for differences between paired transects, or repeated 
Table 1. Equations used in the calculations of within-site, between-site, observer, Bray-Curtis index, and the indirect calculation of temporal variation

\begin{tabular}{|c|c|c|c|c|}
\hline $\begin{array}{l}\text { Equation } \\
\text { description }\end{array}$ & Calculation steps & No. & Equation & $\mathrm{n}$ \\
\hline \multirow[t]{3}{*}{$\begin{array}{l}\text { Within site } \\
\text { coefficient } \\
\text { of variation, } \\
\mathrm{CV}_{1}\end{array}$} & $\begin{array}{l}\text { (I) Site mean }(\mathrm{sm}) \\
S=\text { site } \\
\text { no }=\text { number of observers } \\
n p=\text { number of passes per site } \\
o p=\text { observation per person } \\
\text { per site }\end{array}$ & 1.0 & $\bar{X}_{s}=\frac{\sum_{i=1}^{n o}\left(\frac{\left(\sum_{i=1}^{n p} o p_{i}\right)}{n p}\right)}{n o}$ & $\begin{array}{l}n p=3 \\
n o=5\end{array}$ \\
\hline & $\begin{array}{l}\text { (II) Coefficient of variation } \\
\text { for each site } \\
S=\text { site } \\
n s=\text { number of sites per reef }\end{array}$ & 1.1 & $\mathrm{CV}_{s_{i}}=\frac{\left(\sigma_{s_{i}} \times 100\right)}{\bar{X}_{s_{i}}}$ & $n s=3$ \\
\hline & $\begin{array}{l}\text { (III) Coefficient of variation, } \\
\mathrm{CV}_{1}\end{array}$ & 1.2 & $\mathrm{CV}_{1}=\frac{\left(\sum_{i=1}^{n s} \mathrm{CV} s_{i}\right)}{n s}$ & $n s=3$ \\
\hline \multirow[t]{2}{*}{$\begin{array}{l}\text { Between site coefficient } \\
\text { of variation, } \mathrm{CV}_{2}\end{array}$} & $\begin{array}{l}\text { (I) Average of the site means } \\
(S M=\text { site mean })\end{array}$ & 2.0 & $\bar{X}_{S M}=\frac{\left(\sum_{i=1}^{n s} \bar{X}_{s_{i}}\right)}{n s}$ & $n s=3$ \\
\hline & $\begin{array}{l}\text { (II) Coefficient of variation, } \\
\mathrm{CV}_{2}\end{array}$ & 2.1 & $\mathrm{CV}_{2}=\frac{\left(\sigma_{\bar{X}_{S M}} \times 100\right)}{\bar{X}_{S M}}$ & \\
\hline \multirow[t]{3}{*}{$\begin{array}{l}\text { Observer coefficient } \\
\text { of variation, } \mathrm{CV}_{3}\end{array}$} & $\begin{array}{l}\text { (I) Average per observer } \\
\text { per site }\end{array}$ & 3.0 & $\bar{X}_{o p}=\frac{\left(\sum_{i=1}^{n p} o p_{i}\right)}{n p}$ & $n p=3$ \\
\hline & $\begin{array}{l}\text { (II) Site average based on } \\
\text { observer mean per site } \\
\text { (ops = site average) } \\
\text { (III) Coefficient of variation } \\
\text { per site }\end{array}$ & 3.2 & $\begin{aligned} \bar{X}_{o p s} & =\frac{\left(\sum_{i=1}^{n o} \bar{X}_{o p_{i}}\right)}{n o} \\
\mathrm{CVops}_{i} & =\frac{\left(\sigma_{o p_{i}} \times 100\right)}{\bar{X}_{o p s_{i}}}\end{aligned}$ & $n o=5$ \\
\hline & $\begin{array}{l}\text { (IV) Total observer coefficient } \\
\text { of variation, } \mathrm{CV}_{3}\end{array}$ & 3.3 & $\mathrm{CV}_{3}=\frac{\left(\sum_{i=1}^{n s} \mathrm{CVops} s_{i}\right)}{n s}$ & $n s=3$ \\
\hline $\begin{array}{l}\text { Bray-Curtis } \\
\text { similarity index }\end{array}$ & $\begin{array}{l}B S I=\text { Bray-Curtis similarity } \\
\text { index; } \\
\text { Min }=\text { minimum; } \\
\text { Obs = observer } \\
N=\text { number of species } \\
N r=\text { number of reefs }\end{array}$ & 4.0 & $\begin{array}{c}\bar{X}_{B S I}= \\
\frac{\sum_{i=1}^{N \times n s \times n p}\left[2 \times \min \left(O b s_{1}, O b s_{2}\right) / \sum\left(O b s_{1}, O b s_{2}\right)\right]_{i}}{N \times n s \times n p}\end{array}$ & $\begin{array}{l}N \text { Mombasa }=45 \\
N \text { Rãs }=36 \\
N \text { total }=50 \\
n s=3 \\
n p=3 \\
n r=2\end{array}$ \\
\hline $\begin{array}{l}\text { Temporal coefficient } \\
\text { of variation }\end{array}$ & CV time & 5.0 & CV total - CV space & \\
\hline
\end{tabular}

passes of the same transect. We calculated means and standard deviations for differences in pairs between all 15 passes in each transect and for all 105 possible paired differences. The paired-difference CV for each species in each transect was calculated, and we plotted the CVs derived from paired and unpaired methods against the mean density of each species. Means for the 2 methods were compared with a single-factor ANOVA, and plots of the CV against species popula- tion density were used to make a visual comparison of the paired differences versus mean densities as a function of population density.

Temporal variation. Samples collected in 1992 and 2003 from the MMNP and RAS were used to estimate the temporal variation in the fish numbers and community structure. Data were grouped into the 2 areas and 3 families (Acanthuridae, Scaridae, and Pomacentridae). Similarities of 64 paired combinations from RAS 
and the MMNP in both time periods were calculated, and the mean similarity for each reef-time-pair combination was derived. CVs were then calculated for the total, spatial, and temporal variation.

Total variation was calculated from the mean and standard deviation of the 16 replicates in both areas in the 2 years. A mean and standard deviation of the 4 replicates in each area and year were also calculated. The coefficient of spatial variation was calculated from the average of these means and the standard deviations. The coefficient of temporal variation was estimated using 2 methods: (1) directly comparing means over time as above using the means for each area and year, and (2) subtracting the mean within spatial variation from the total variation (Eq. 5.0, Table 1). The first is a direct comparison of means over time and the second is an indirect method where the temporal variation is the variation remaining after the mean spatial variation has been subtracted from the total variation.

Power to detect differences. In order to establish the sample sizes required to detect given differences in reef fish assemblages and individual species, we carried out a power analysis in the MiniTab statistical package. From the variances of the 3 transects in each area surveyed in 2004 and using a 1-way ANOVA model, we calculated the percent change detectable at the 0.05 alpha level with a power of $80 \%$ for each species. We used an $\mathrm{n}$ of $4,10,20$, and 30, which represents sample sizes often used at the scale of both site and study area in fish population studies (McClanahan 1994, Jennings et al. 1995, Samoilys \& Carlos 2000, Graham et al. 2006).

\section{RESULTS}

There were no statistically significant differences between observers (MANOVA, $F=5.1$ ), but the areas differed substantially (MANOVA, $F=59.7, \mathrm{p}<$ 0.0001) while sites nested within areas also differed (MANOVA, $F=15.9, \mathrm{p}<$ 0.003). These between-area differences and similarities among observers are highlighted by the MDS plot (Fig. 1).
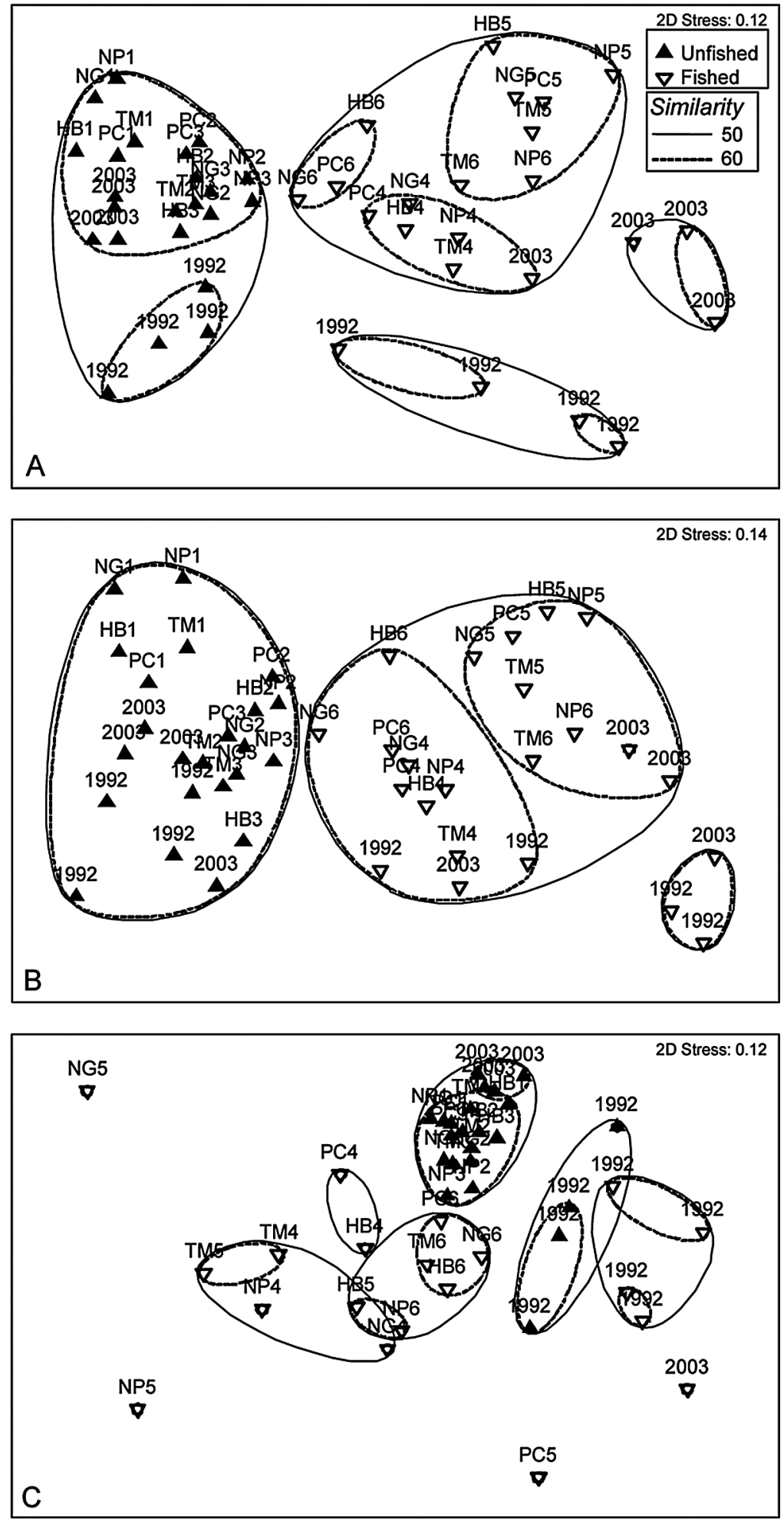

Fig 1. Multi-dimensional scaling (MDS) plots with similarity slices of 50 and 60 overlaid for the different passes of each transect within 2 different management areas for both temporal (1992 and 2003) data and multiple observer (initials identify observer) data. (A) Whole assemblage combined, (B) Pomacentrids and (C) scarids and acanthurids combined in both Ras Iwatine (RAS; fished) and the Mombasa Marine National Park (MMNP; unfished) 


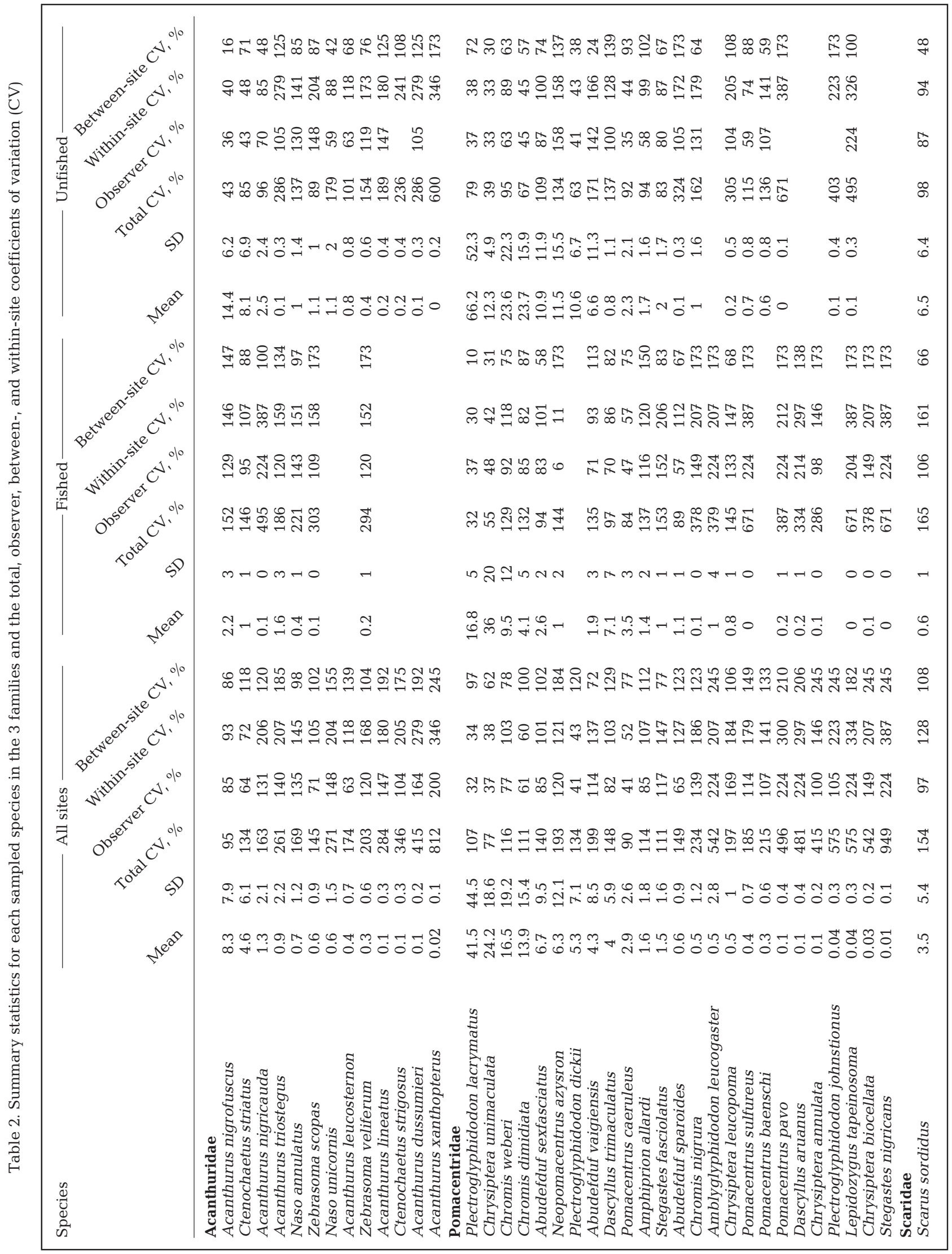




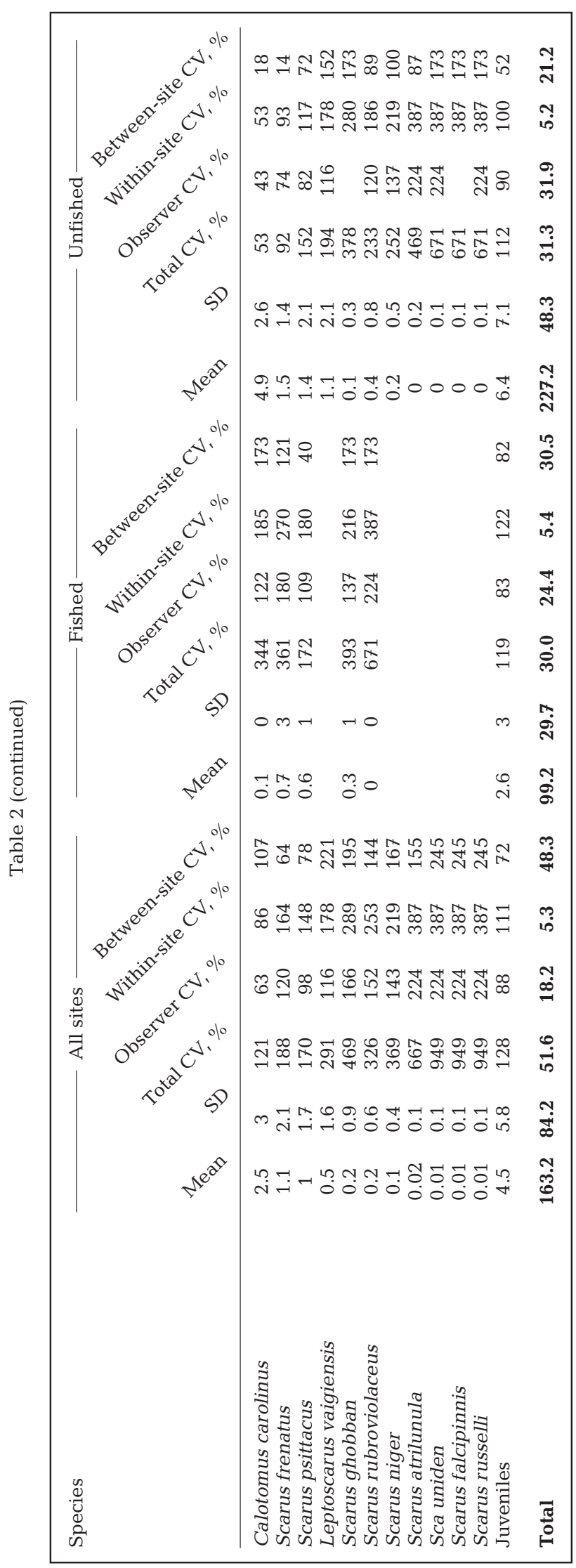

For the whole sampled assemblage, data points for 1992 and 2003 were distinct from each other; those for 2003 tended to be more similar to the 2004 data than those from 1992, with greatest departure seen in the fished area (Fig. 1A). This pattern was particularly clear for the mobile scarid and acanthurid group (Fig. 1C), with greatest variation shown for the fished area, and recovery of these fish from 1992 to 2003/4 evident in the unfished area. The more sedentary pomacentrids showed much less variation, particularly in the unfished area (Fig. 1B). Observations generally grouped by management in the unfished area and transect in the fished area, although greater variation was apparent in the mobile scarid and acanthurid group, particularly for the broken transect (Site 5).

Variations in the abundance of all species were large, most species having CVs $>100 \%$ (Table 2). The few exceptions were dominant damselfish species such as Plectroglyphidodon lacrymatus and Chrysiptera unimaculata that had overall within-site CVs approximating $35 \%$. The most abundant surgeonfish Acanthurus nigrofuscus and Ctenochaetus striatus had overall CVs of 93 and $72 \%$, respectively, with lower CVs (40 and $48 \%$, respectively) in the MMNP. Variation, as measured by standard deviations, was positively related to mean abundances $\left(\mathrm{R}^{2}=0.95 ; y=\right.$ $0.52+0.98 x$ ), but relative to the means, both the highest and lowest CVs were found for species of low abundance and did not differ $(F=1.72, \mathrm{p}=0.20)$ if variation around the mean $(\mathrm{CV}=151 \pm 60)$ or differences between paired means $(\mathrm{CV}=139 \pm 56)$ were used to calculate the CV (Fig. 2). Despite substantial variation in data of individual species, the variation around the total number of individuals was low, the CV being only $5 \%$ within sites and $48 \%$ between sites and similar between RAS and the MMNP (Table 2).

Variations in total abundance were greater at RAS than in the MMNP and greater for acanthurids/scarids than for pomacentrids (Table 3). Mean between-site and between-observer CVs among species were higher at RAS than in the MMNP, but within-site variation was greatest overall and did not differ between areas (Table 3). For the acanthurids/scarids and pomacentrids as individual groups, the magnitudes of the differences were indistinguishable. When comparing observer, within-, and between-site sources of variation, within-site variation was consistently the greatest for the whole assemblage and the acanthurid/scarid group (Table 3).

The maximum similarity in community composition achievable was $\sim 80 \%$ for between-observer comparisons, and this was similar to the level of within-site variation (Table 4). Similarity dropped to $58-67 \%$ for between-site comparisons. Community similarity was higher for pomacentrids than acanthurids/scarids, and 


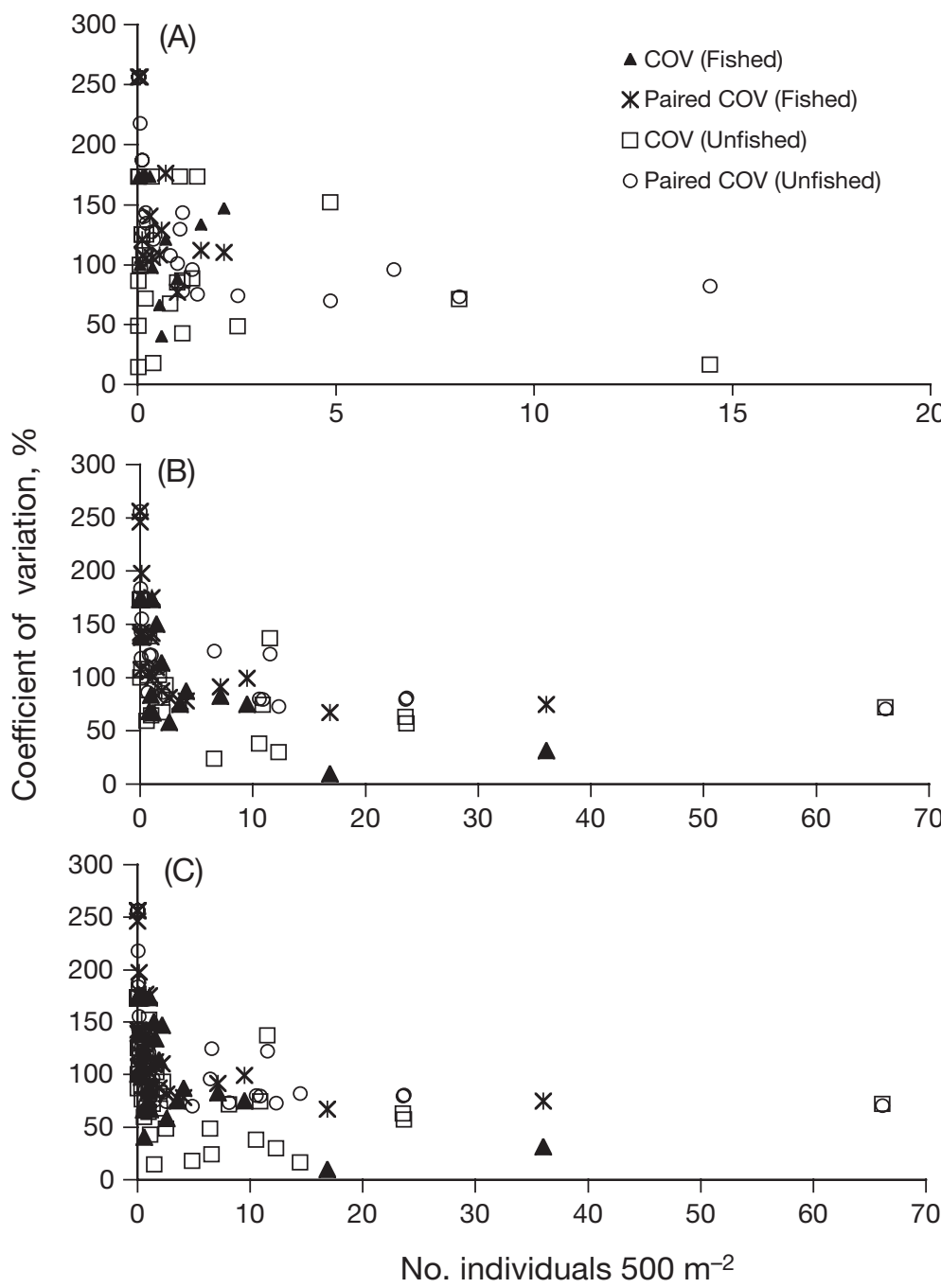

Fig. 2. Plots of coefficients of variation (CVs) against mean abundances for (A) the whole assemblage, (B) pomacentrids, and (C) the scarid and acanthurid groups for both variations around the mean and differences between paired transects in both RAS (fished) and MMNP (unfished)
RAS (17\% and $43 \%$ respectively) over the $\sim 10$ yr period (Table 5).

Most species required large sample sizes to detect small to modest changes in abundance data, with smaller changes being detectable in the MMNP than at RAS for most comparisons, although this varied with family and species (Table 6). At the family level, scarids required the least sampling to detect change, followed by the pomacentrids and the acanthurids at RAS. However, in the MMNP the pomacentrids required the least sampling. At the species level there were a few species in the MMNP that did not require extensive sampling to detect modest change. For example, Acanthurus nigrofuscus and 2 parrotfish, Calotomus carolinus and Scarus frenatus, required only 4 transects to detect changes $<50 \%$ (Table 6). At RAS, modest sample sizes of 10 transects could detect changes $<50 \%$ for the 2 common damselfish Plectroglyphidodon lacrymatus and Chrysiptera unimaculata, but changes $<100 \%$ are unlikely to be detected for any surgeonfish and only a few parrotfish at typical levels of sample replication.

Estimates of species variation over time were sensitive to the method of calculation, with the direct method of comparing means producing higher values than the indirect estimate derived by subtracting the mean spatial from the total variation (Table 7). In most cases the direct method indicated temporal variation to be about twice as great as the indirect method. Patterns with respect to family groups and area were consistent with the above measurements. there were fewer differences between the 2 areas (Table 4). Over $\sim 10 \mathrm{yr}$, the maximum similarity for all fish was 37 and $58 \%$ when comparing RAS and the MMNP, respectively (Table 5). For the overall species assemblage and for acanthurids/scarids, there tended to be higher community similarity for the MMNP than for RAS for between-observer and within- and between-site comparisons (Table 4). The pomacentrid community similarity was higher among observers in the MMNP than at RAS, but there were no differences for between- and within-site comparisons (Table 4). For the whole assemblage and for the 2 taxonomic groups, the between-site community similarity was always lower than that between observers and within sites (Table 4). There was greater community similarity in the MMNP for acanthurids/scarids (43\%) and pomacentrids (64\%) than at

\section{DISCUSSION}

We set out to quantify various sources of population and community variability among coral reef fishes and the role of instantaneous variation on estimates of changes over time. The high instantaneous variation measured in this study indicates that this previously ignored factor is the largest source of variation for the populations of the species surveyed and can lead to difficulties in detecting differences between sampling methods, sites, management, and time (Samoilys \& Carlos 2000). High within-site variability has been observed in other studies (Sale \& Douglas 1984, Ault \& Johnson 1998, Samoilys \& Carlos 2000, Gust et al. 2001, Thompson \& Mapstone 2002) and has been presented as evidence that fish assemblages are not in equilib- 
Table 3. Summary of coefficients of variation of fish population density in all sites (=transect) and the fished and unfished reefs and ANOVA tests of significance. Tukey test for post hoc comparisons given, where ws = within sites, bs = between sites, and bo = between observers

\begin{tabular}{|c|c|c|c|c|c|}
\hline & \multirow[t]{2}{*}{ All sites } & \multirow[t]{2}{*}{ Fished } & \multirow[t]{2}{*}{ Unfished } & \multicolumn{2}{|c|}{$\begin{array}{l}\text { Management } \\
1 \text {-way ANOVA }\end{array}$} \\
\hline & & & & $F$ & $\mathrm{p}$ \\
\hline \multicolumn{6}{|c|}{ Acanthuridae and Scaridae } \\
\hline Total variation & 354.0 & 300.2 & 256.7 & 0.3 & 0.56 \\
\hline Observer & 134.9 & 139.8 & 112.1 & 1.9 & 0.17 \\
\hline Within site & 209.8 & 204.5 & 199.7 & 0.0 & 0.94 \\
\hline Between sites & 152.2 & 127.6 & 96.9 & 3.1 & 0.09 \\
\hline$F$ ratio & 5.0 & 4.2 & 7.4 & & \\
\hline $\mathrm{p}$ & 0.01 & 0.02 & 0.002 & & \\
\hline Tukey test & $\mathrm{ws}>\mathrm{bs}$, bo & bs $<$ ws, bo & $\mathrm{bs}<\mathrm{ws}$, bo & & \\
\hline \multicolumn{6}{|l|}{ Pomacentridae } \\
\hline Total variation & 284 & 254 & 92 & 1.3 & 0.27 \\
\hline Observer & 118 & 123 & 89 & 2.8 & 0.10 \\
\hline Within site & 159 & 166 & 137 & 0.8 & 0.38 \\
\hline Between sites & 147 & 118 & 92 & 2.7 & 0.11 \\
\hline$F$ ratio & 1.9 & 1.6 & 2.2 & & \\
\hline $\mathrm{p}$ & 0.15 & 0.21 & 0.13 & & \\
\hline \multicolumn{6}{|c|}{ Whole assemblage } \\
\hline Total variation & 320 & 267 & 224 & 1.1 & 0.31 \\
\hline Observer & 127 & 128 & 101 & 4.0 & 0.05 \\
\hline Within site & 185 & 178 & 170 & 0.1 & 0.73 \\
\hline Between sites & 150 & 120 & 94 & 5.8 & 0.02 \\
\hline F ratio & 7 & 4.44 & 9.36 & & \\
\hline $\mathrm{p}$ & 0.0 & 0.016 & 0.0002 & & \\
\hline Tukey test & ws $>$ bo & $\mathrm{ws}>\mathrm{bo}, \mathrm{bs}$ & $\mathrm{ws}>\mathrm{bo}, \mathrm{bs}$ & & \\
\hline
\end{tabular}

rium with their resources (Sale \& Douglas 1984). Our study shows, however, that as much as 15 to $25 \%$ of this within-site community variation is essentially instantaneous or on a time scale considerably faster than reproductive and mortality processes that would potentially reflect population responses to resources.

The amount of variation in sampling is similar to the community similarity predictions of neutral theory, where neutral theory predicts that reef corals will have Bray-Curtis similarities between 70 and $85 \%$, whereas actual coral communities have considerably lower similarities, presumably due to non-random processes (Dornelas et al. 2006). Consequently, because a high percentage of the total variation is essentially instantaneous, estimating temporal variation and determining underlying population or ecological processes is difficult. Our 2 methods for calculating temporal variation produced considerably different estimates. For the analysis of individual populations, removing spatial variation from estimates of temporal change reduced the estimate of change by half. We suggest that temporal variation is often over-estimated because of the problems of instantaneous variation where estimated variation is confounded by variation at very small temporal scales. Therefore, we suggest that coral reef fish are more stable in terms of birth and death processes than previous comparisons of means over time. Random walks have previously been used to account for temporal variability (Ault \& Johnson 1998), and their use needs to be compared with our field-based method to determine their accuracy in estimating instantaneous variation.

High instantaneous variation will reduce the efficacy of estimating fish populations and communities, because real but minor changes will go undetected due to this inherent variability and the low to moderate sample sizes commonly used in coral reef fish studies. This is commonly observed in short-term efforts to quantify change over daily and tidal cycles (Mapstone \& Thomson 2002, Willis et al. 2006). There may be cycles, but they are not strong enough to be distinguishable from population noise; therefore, efforts to quantify them are likely to produce false negatives. Future efforts to examine temporal patterns will need to quantify instantaneous variation or noise in order to estimate the strength of weak signals.

We attempted a paired test, which is a common method, to reduce variation and detect changes when between- is larger than within-sample variation. However, we found that it did not reduce variation, which can be attributed to the high withinsite or instantaneous variation. The explicit intent of monitoring fixed sites over time as repeated or paired sampling of the same site is to reduce variation and increase the power to detect smaller change. The consequence, however, is that repetition of the same sites reduces the opportunity for replication in space, the associated degrees of freedom, and the generality of the findings. When within-site is equal or higher than between-site variation, as found for most of our studied species, monitoring programs would be better suited to increase the number of transects and sites rather than repetition of the same sites over time. This would also have the benefit of increasing the spatial generality of the findings.

Despite higher within-site population variability, we found higher community similarity within than between sites. Community similarity will be most influenced by dominant species, and because these dominants have the lowest instantaneous variation, community similarity will reflect this and produce lower within- than between-site variation. This suggests that change is more likely to be detected for dom- 
Table 4. Mean percent similarities (Bray-Curtis index) between observer, within sites, and between sites in all sites, fished and unfished management areas. A 1-way comparison Tukey test for post hoc comparisons is given, where ws $=$ within sites, bs $=$ between sites, and bo = between observers

\begin{tabular}{|c|c|c|c|c|c|c|c|c|}
\hline & \multicolumn{2}{|c|}{ — All sites -} & - Fished — & $\overline{\mathrm{SD}}$ & $\begin{array}{c}\text { Unfis } \\
\text { Mean }\end{array}$ & $\overline{\mathrm{SD}}$ & \multicolumn{2}{|c|}{$\begin{array}{l}\text { Management, } \\
\text { 1-way ANOVA }\end{array}$} \\
\hline & & & & & & & $F$ & $\mathrm{p}$ \\
\hline \multicolumn{9}{|c|}{ Acanthuridae and Scaridae } \\
\hline Between observers & 71.0 & 11.5 & 62.3 & 8.1 & 79.8 & 6.4 & 28.8 & 0.001 \\
\hline Between sites & 52.7 & 24.1 & 35.2 & 22.0 & 68.1 & 8.1 & 33.3 & 0.001 \\
\hline Within site & 59.7 & 28.4 & 43.5 & 23.8 & 75.9 & 3.4 & $43.2^{\mathrm{a}}$ & 0.001 \\
\hline$F$ ratio & 8.0 & & $12.6^{\mathrm{a}}$ & & 5.4 & & & \\
\hline Prob $>F$ & 0.001 & & 0.001 & & 0.01 & & & \\
\hline Tukey test & bo, ws $>$ bs & & & & $\mathrm{ws}, \mathrm{bo}>\mathrm{bs}$ & & & \\
\hline \multicolumn{9}{|l|}{ Pomacentridae } \\
\hline Between observers & 84.4 & 4.3 & 81.8 & 4.0 & 87.1 & 2.8 & 11.7 & 0.003 \\
\hline Between sites & 64.3 & 7.3 & 62.9 & 6.4 & 65.6 & 8.0 & 1.0 & 0.33 \\
\hline Within site & 87.9 & 5.0 & 88.6 & 2.5 & 87.3 & 1.7 & 0.5 & 0.5 \\
\hline F ratio & 135.4 & & 136.0 & & 89.4 & & & \\
\hline Prob $>F$ & $<0.0001$ & & $<0.0001$ & & $<0.0001$ & & & \\
\hline Tukey test & $\mathrm{ws}>\mathrm{bo}>\mathrm{bs}$ & & $\mathrm{ws}>\mathrm{bo}>\mathrm{bs}$ & & $\mathrm{bo}, \mathrm{ws}>\mathrm{bs}$ & & & \\
\hline \multicolumn{9}{|l|}{ Whole assemblage } \\
\hline Between observers & 80.8 & 5.1 & 77.3 & 4.4 & 84.3 & 2.7 & 18.4 & 0.0001 \\
\hline Between sites & 62.6 & 7.7 & 57.8 & 5.7 & 67.4 & 6.5 & 18.1 & 0.0001 \\
\hline Within site & 83.5 & 4.3 & 83.4 & 2.0 & 83.6 & 0.5 & 0.0 & 0.91 \\
\hline$F$ ratio & 97.2 & & 136 & & 91.0 & & & \\
\hline Prob $>F$ & $<0.0001$ & & $<0.0001$ & & $<0.0001$ & & & \\
\hline Tukey test & bo,ws $>$ bs & & $\mathrm{ws}>\mathrm{bo}>\mathrm{bs}$ & & $\mathrm{bo}, \mathrm{ws}>\mathrm{bs}$ & & & \\
\hline aWelch's ANOVA & & & & & & & & \\
\hline
\end{tabular}

Table 5. Mean percent similarities (Bray-Curtis index) of the studied reefs over 2 time periods

\begin{tabular}{|c|c|c|c|}
\hline & $\begin{array}{c}\text { Unfished } \\
1992\end{array}$ & $\begin{array}{c}\text { Fished } \\
1992\end{array}$ & $\begin{array}{c}\text { Unfished } \\
2003\end{array}$ \\
\hline \multicolumn{4}{|c|}{ Acanthuridae and Scaridae } \\
\hline Fished 1992 & 36.1 & & \\
\hline Unfished 2003 & 42.5 & 35.4 & \\
\hline Fished 2003 & 9.8 & 16.5 & 6.9 \\
\hline \multicolumn{4}{|l|}{ Pomacentridae } \\
\hline Fished 1992 & 35.9 & & \\
\hline Unfished 2003 & 64.1 & 33.3 & \\
\hline Fished 2003 & 36.6 & 42.6 & 44.8 \\
\hline \multicolumn{4}{|l|}{ All assemblages } \\
\hline Fished 1992 & 35.9 & & \\
\hline Unfished 2003 & 57.7 & 34.1 & \\
\hline Fished 2003 & 33.1 & 37.4 & 33.5 \\
\hline
\end{tabular}

inant species and community similarity when using repeated or paired sampling and low levels of replication. Similarly, pooling of species into family groups also reduced the $\mathrm{CV}$, and other forms of pooled data, such as numbers of species per site or functional groupings, would be expected to detect change at smaller sample sizes (Rahel 1990). Consequently, repeated-site monitoring programs will be most successful at detecting change for aggregate or pooled measures, including community, family, or functional groups. Detecting change in many moderately common or rare coral reef fish species may be unrealistic at currently common sampling levels, and the lack of significantly measured change may often be due to lack of statistical power rather than lack of change. Aggregation, the size of the sample, the sampling area, and the size of the community sampled can influence conclusions about the role of deterministic versus stochastic processes in ecosystems (Rahel et al. 1984, Ebeling et al. 1990, Rahel 1990), and coral reef fishes appear to fit this general pattern.

Across species, CVs of abundance were more variable at low population densities, with variation often 2 or 3 times larger than the means. Fishing reduces population densities and therefore increases the patchiness of the distributions. Detection associated with greater flight distances or movement of fish in fished reefs can also be expected to increase population and community variation (Kulbicki 1998, Willis et al. 2006). However, it is not inevitable that lower population densities increase the $\mathrm{CV}$, as we observed a number of species with both low population densities and CVs. CVs were simply more unpredictable at low popula- 
Table 6. Percentage change detectable for each species surveyed and the 3 families within different management areas with sample sizes of $4,10,20$, and 30. Calculated for a power of 0.8 and with an alpha level of 0.05

\begin{tabular}{|c|c|c|c|c|c|c|c|c|}
\hline \multirow[t]{2}{*}{ Species } & \multicolumn{4}{|c|}{$\begin{array}{l}\text { Fished } \\
\text { Percentage change detectable }\end{array}$} & \multicolumn{4}{|c|}{$\begin{array}{l}\text { Unfished } \\
\text { Percentage change detectable }\end{array}$} \\
\hline & $\mathrm{n}=4$ & $\mathrm{n}=10$ & $\mathrm{n}=20$ & $\mathrm{n}=30$ & $\mathrm{n}=4$ & $\mathrm{n}=10$ & $\mathrm{n}=20$ & $\mathrm{n}=30$ \\
\hline \multicolumn{9}{|l|}{ Acanthuridae } \\
\hline Acanthurus nigrofuscus & 384 & 216 & 148 & 120 & 43 & 24 & 16 & 13 \\
\hline Ctenochaetus striatus & 231 & 130 & 89 & 72 & 187 & 105 & 72 & 58 \\
\hline Acanthurus nigricauda & 263 & 148 & 101 & 82 & 126 & 71 & 49 & 39 \\
\hline Acanthurus triostegus & 348 & 196 & 135 & 109 & 327 & 184 & 126 & 102 \\
\hline Naso annulatus & 254 & 143 & 98 & 79 & 223 & 125 & 86 & 69 \\
\hline Zebrasoma scopas & 454 & 254 & 175 & 141 & 227 & 127 & 87 & 71 \\
\hline Naso unicornis & & & & & 111 & 62 & 43 & 35 \\
\hline Acanthurus leucosternon & & & & & 177 & 99 & 68 & 55 \\
\hline Zebrasoma veliferum & 453 & 254 & 175 & 141 & 200 & 112 & 77 & 62 \\
\hline Acanthurus lineatus & & & & & 327 & 182 & 126 & 102 \\
\hline Ctenochaetus strigosus & & & & & 283 & 159 & 109 & 88 \\
\hline Acanthurus dussumieri & & & & & 327 & 184 & 126 & 102 \\
\hline Acanthurus xanthopterus & & & & & 452 & 254 & 174 & 141 \\
\hline \multicolumn{9}{|l|}{ Pomacentridae } \\
\hline Plectroglyphidodon lacrymatus & 25 & 14 & 10 & 8 & 188 & 106 & 72 & 59 \\
\hline Chrysiptera unimaculata & 82 & 46 & 32 & 26 & 78 & 44 & 30 & 24 \\
\hline Chromis weberi & 195 & 110 & 75 & 61 & 165 & 92 & 63 & 51 \\
\hline Chromis dimidiata & 227 & 128 & 88 & 71 & 149 & 84 & 57 & 46 \\
\hline Abudefduf sexfasciatus & 151 & 85 & 58 & 47 & 195 & 109 & 75 & 61 \\
\hline Neopomacentrus azysron & 453 & 254 & 175 & 141 & 358 & 201 & 138 & 112 \\
\hline Plectroglyphidodon dickii & & & & & 99 & 56 & 38 & 31 \\
\hline Abudefduf vaigiensis & 297 & 167 & 114 & 93 & 62 & 35 & 24 & 19 \\
\hline Dascyllus trimaculatus & 215 & 121 & 83 & 67 & 363 & 204 & 140 & 113 \\
\hline Pomacentrus caeruleus & 195 & 110 & 75 & 61 & 243 & 136 & 94 & 76 \\
\hline Amphiprion allardi & 392 & 220 & 151 & 122 & 267 & 150 & 103 & 83 \\
\hline Stegastes fasciolatus & 218 & 122 & 84 & 68 & 176 & 99 & 68 & 55 \\
\hline Abudefduf sparoides & 175 & 98 & 67 & 54 & 453 & 254 & 175 & 141 \\
\hline Chromis nigrura & 452 & 253 & 174 & 141 & 168 & 94 & 65 & 52 \\
\hline Amblyglyphidodon leucogaster & 454 & 254 & 175 & 141 & & & & \\
\hline Chrysiptera leucopoma & 178 & 100 & 69 & 55 & 283 & 159 & 109 & 88 \\
\hline Pomacentrus sulfureus & 448 & 251 & 172 & 140 & 230 & 129 & 89 & 72 \\
\hline Pomacentrus baenschi & & & & & 155 & 87 & 60 & 48 \\
\hline Pomacentrus pavo & 453 & 254 & 175 & 141 & 448 & 251 & 172 & 140 \\
\hline Dascyllus aruanus & 361 & 202 & 139 & 112 & & & & \\
\hline Chrysiptera annulata & 452 & 254 & 174 & 141 & & & & \\
\hline Plectroglyphidodon johnstionus & & & & & 453 & 254 & 175 & 141 \\
\hline Lepidozygus tapeinosoma & 448 & 251 & 172 & 140 & 263 & 148 & 101 & 82 \\
\hline Chrysiptera biocellata & 452 & 253 & 174 & 141 & & & & \\
\hline Stegastes nigricans & 448 & 251 & 172 & 140 & & & & \\
\hline \multicolumn{9}{|l|}{ Scaridae } \\
\hline Scarus sordidus & 173 & 97 & 67 & 54 & 127 & 71 & 49 & 40 \\
\hline Calotomus carolinus & 452 & 254 & 174 & 141 & 47 & 26 & 18 & 15 \\
\hline Scarus frenatus & 317 & 178 & 122 & 99 & 37 & 21 & 14 & 12 \\
\hline Scarus psittacus & 105 & 59 & 40 & 33 & 188 & 106 & 72 & 59 \\
\hline Leptoscarus vaigiensis & & & & & 398 & 223 & 153 & 124 \\
\hline Scarus ghobban & 453 & 254 & 175 & 141 & 452 & 253 & 174 & 141 \\
\hline Scarus rubroviolaceus & 448 & 251 & 172 & 140 & 232 & 130 & 89 & 72 \\
\hline Scarus niger & & & & & 262 & 147 & 101 & 82 \\
\hline Scarus atrilunula & & & & & 224 & 126 & 86 & 70 \\
\hline Scarus spp. & & & & & 448 & 251 & 172 & 140 \\
\hline Scarus falcipinnis & & & & & 448 & 251 & 172 & 140 \\
\hline Scarus russelli & & & & & 448 & 251 & 172 & 140 \\
\hline Juveniles & 213 & 120 & 82 & 66 & 137 & 77 & 53 & 43 \\
\hline Acanthuridae & 280 & 157 & 108 & 87 & 101 & 57 & 39 & 31 \\
\hline Pomacentridae & 66 & 37 & 25 & 21 & 48 & 27 & 18 & 15 \\
\hline Scaridae & 29 & 16 & 11 & 9 & 70 & 40 & 27 & 22 \\
\hline
\end{tabular}


Table 7. Average of the species coefficients of variation for the studied fish groups for comparisons of field sampling in 1992 and 2003 and for 2 methods for estimating temporal variation

\begin{tabular}{|c|c|c|c|c|}
\hline & \multirow[b]{2}{*}{ Total } & \multicolumn{2}{|c|}{ Temporal variation } & \multirow[b]{2}{*}{$\begin{array}{c}\text { Indirect } \\
\text { (Total- } \\
\text { Space) }\end{array}$} \\
\hline & & Space & $\begin{array}{c}\text { Direct } \\
\text { comparison } \\
\text { of means }\end{array}$ & \\
\hline \multicolumn{5}{|l|}{ Unfished } \\
\hline Acanthuridae and Scaridae & 192.8 & 129.0 & 122.3 & 63.8 \\
\hline Pomacentridae & 132.5 & 87.3 & 101.2 & 45.2 \\
\hline All fish & 161.9 & 107.6 & 111.5 & 54.3 \\
\hline \multicolumn{5}{|l|}{ Fished } \\
\hline Acanthuridae and Scaridae & 217.7 & 144.3 & 138.1 & 73.4 \\
\hline Pomacentridae & 201.0 & 146.2 & 111.2 & 54.8 \\
\hline All fish & 206.9 & 145.5 & 120.8 & 61.4 \\
\hline \multicolumn{5}{|l|}{ All reefs } \\
\hline Acanthuridae and Scaridae & 202.6 & 118.2 & 168.7 & 84.5 \\
\hline Pomacentridae & 187.2 & 113.5 & 148.3 & 73.8 \\
\hline All fish & 194.7 & 115.6 & 157.5 & 79.2 \\
\hline
\end{tabular}

tion densities. Consequently, determining population change in many rare species will be difficult without large replication.

In some cases, experienced observers have been shown to bias estimates of fish length, transect width, and the flight distance of fish (Kulbicki 1998, Edgar et al. 2004, Harvey et al. 2004). These biases may be sufficiently consistent between observers that the relative effects are small (Williams et al. 2006). Nonetheless, the bias could influence outcomes for important aspects of ecology where absolute measures are required, such as of fish biomass and derived estimates of consumption and energy requirements. Kulbicki (1998) suggested that comparisons of reserve and nonreserve sites are biased by the flight response of fish in environments with different levels of human use. Our study suggests, however, that differences between fished and unfished sites can be due to reduced densities and higher population variation in unfished reefs.

Variation will increase as the size of the sampled area is reduced. Compared to many studies that sampled areas of $250 \mathrm{~m}^{2}$ or less (Jennings et al. 1995, English et al. 1997), we used a relatively large area. Consequently, methods using smaller areas will have higher variation and more difficulty detecting differences and change without large replication (Samoilys \& Carlos 2000). However, greater replication required less effort for smaller sample sizes, and it is not clear without further work which combination of sample size unit and replication for a given effort will yield the least variation.

Life history, ecological, and behavioral characteristics of fish species will also influence the ability to detect change. Life history characteristics such as growth, longevity, recruitment variability, and population turnover rates will all affect responses to natural perturbations or cessation from fishing (Connell \& Sousa 1983, McClanahan \& Graham 2005, Wilson et al. 2006), and species maximum attainable length is a useful surrogate for many of these characteristics (Jennings et al. 1999). Movement pattern, the extent of aggregation into schools, or preferred habitat can greatly influence spatial variance (Ault \& Johnson 1998, Graham et al. 2003), and this is highlighted by the sample sizes needed to detect change in some of the schooling planktivorous damselfish species. Movements relating to tidal and diurnal rhythms, seasonality, and the home range size can vary between species and with local geography (Galzin 1987, Zeller 1997, Kramer \& Chapman 1999, Thompson \& Mapstone 2002) and require standardization when possible to improve the chances of detecting real change.

\section{CONCLUSIONS}

There is inherent and near-instant variation in fish communities that makes it difficult to detect temporal change in most coral reef fish species using common field methods. This is probably due to a combination of the high movement, the patchy spatial distribution of many coral reef species, and some observer differences. Detecting differences over time by repeated sampling of sites will be most feasible for only a few of the most abundant species and for pooled measures such as community-level analyses, numbers of species, taxonomic families, and functional groups. Detection of species-level changes will be difficult unless changes $>100 \%$ occur, but would be more likely without repeated site sampling because of higher withinthan between-site variation and fewer degrees of freedom. Because spatial variation confounds direct estimates of temporal change, the magnitude of change in species numbers over time is probably about half the estimates of past methods that directly compared means. We did detect significant community change in the 2 reefs over a 10 yr period, but the study sites were both influenced by a cessation and continuation of fishing and the tendency of species assemblages to diverge over time (Bengtsson et al. 1997). Temporalchange estimates that eliminate spatial variation suggest that where fishing effects are small, coral reef fish 
are more stable than previous estimates. Future work will need to estimate the instantaneous variation in their samples before making reasonable estimates of temporal population variation.

Acknowledgements. This work resulted from a workshop sponsored by the Western Indian Ocean Marine Science Association (WIOMSA) Marine Science for Management (MASMA) program. The Leverhulme Trust provided additional funding to N.A.J.G. and N.V.C.P. We thank R. Quatre, G. Rosine, M. Ateweberhan, and the warden and rangers of the Mombasa Marine National Park for field assistance. We thank A. Stewart-Oaten for useful comments on a draft of the manuscript.

\section{LITERATURE CITED}

Ault TR, Johnson CR (1998) Spatial variation in fish species richness on coral reefs: habitat fragmentation and stochastic structuring processes. Oikos 82:354-364

Bengtsson J, Baillie SR, Lawton J (1997) Community variability increases with time. Oikos 78:249-256

Bohnsack JA (1983) Species turnover and the order versus chaos controversy concerning reef fish community structure. Coral Reefs 1:223-228

Brock RE (1982) A critique of the visual census method for assessing coral reef fish populations. Bull Mar Sci 32:269-276

Clark KR, Warwick RM (2001) Change in marine communities: an approach to statistical analysis and interpretation, 2nd ed. PRIMER-E, Plymouth

Connell JH, Sousa WP (1983) On the evidence needed to judge ecological stability or persistence. Am Nat 121: 789-824

Cros A, McClanahan TR (2003) Coral transplant damage under various management conditions in the Mombasa Marine National Park, Kenya. West Indian Ocean J Mar Sci 2:127-136

Doherty PJ, Williams DM (1988) Are populations of coral reefs fishes equilibrial assemblages? The empirical database. In: Choat JH, Barnes D, Borowitzka MA, Coll JC and 14 others (eds) 6th Int Coral Reef Symp, Townsville, Australia, 8-12 Aug 1988, p 131-139

Dornelas M, Connolly SR, Hughes TP (2006) Coral reef diversity refutes the neutral theory of biodiversity. Nature 440: 80-82

Ebeling AW, Holbrook SJ, Schmitt RJ (1990) Temporally concordant structure of a fish assemblage: bound or determined? Am Nat 135:63-73

Edgar GJ, Barrett NS, Morton AJ (2004) Biases associated with the use of underwater visual census techniques to quantify the density and size-structure of fish populations. J Exp Mar Biol Ecol 308:269-290

English S, Wilkinson C, Baker V (1997) Survey manual for tropical marine resources. Australian Institute of Marine Science, Townsville

Fowler AJ (1987) The development of sampling strategies for population studies of coral reef fishes. A case study. Coral Reefs 6:49-58

Galzin R (1987) Structure of fish communities of French Polynesian coral reefs. II. Temporal scales. Mar Ecol Prog Ser 41:137-145

Galzin R, Planes S, Dufour V, Salvat B (1994) Variation in diversity of coral reef fish between French Polynesian atolls. Coral Reefs 13:175-180
Graham NAJ, Evans RD, Russ GR (2003) The effects of marine reserve protection on the trophic relationships of reef fishes on the Great Barrier Reef. Environ Conserv 30: 200-208

Graham NAJ, Wilson SK, Jennings S, Polunin NVC, Bijoux JP, Robinson J (2006) Dynamic fragility of oceanic coral reef ecosystems. Proc Natl Acad Sci USA 103:8425-8429

Greene LE, Alevizon WS (1989) Comparative accuracies of visual assessment methods for coral reef fishes. Bull Mar Sci 44:899-912

Gust N, Choat JH, McCormick MI (2001) Spatial variability in reef fish distribution, abundance, size and biomass: a multi-scale analysis. Mar Ecol Prog Ser 214:237-251

Halford A, Cheal AJ, Ryan CD, Williams DM (2004) Resilience to large-scale disturbance in coral and fish assemblages on the Great Barrier Reef. Ecology 85: 1892-1905

Harvey E, Fletcher D, Shortis MR, Kendrick GA (2004) A comparison of underwater visual distance estimates made by scuba divers and a stereo-video system: implications for underwater visual census of reef fish abundance. Mar Freshw Res 55:573-580

Helfman GS (1986) Fish behavior by day, night and twilight In: Pitcher TJ (ed) The behaviour of teleost fishes. Johns Hopkins University Press, Baltimore, MD, p 366-387

Hixon MA, Carr MH (1997) Synergistic predation, density dependence, and population regulation in marine fish. Science 277:946-949

Jennings S, Grandcourt EM, Polunin NVC (1995) The effects of fishing on the diversity, biomass and trophic structure of Seychelles' reef fish communities. Coral Reefs 14:225-235

Jennings S, Reynolds JD, Polunin NVC (1999) Predicting the vulnerability of tropical reef fishes to exploitation with phylogenies and life histories. Conserv Biol 13:1466-1475

Jones GP, McCormick MI, Srinivasan M, Eagle JV (2004) Coral decline threatens fish biodiversity in marine reserves. Proc Natl Acad Sci USA 101:8251-8258

Kramer DL, Chapman MR (1999) Implications of fish home range size and relocation for marine reserve function. Environ Biol Fishes 55:65-79

Kulbicki M (1998) How the acquired behaviour of commercial reef fishes may influence the results obtained from visual censuses. J Exp Mar Biol Ecol 222:11-30

Kulbicki M, Sarramegna S (1999) Comparison of density estimates derived from strip transect and distance sampling for underwater visual censuses: a case study of Chaetodontidae and Pomacanthidae. Aquat Living Resour 12:315-325

Lieske E, Myers R (1994) Coral reef fishes: Indo-Pacific and Caribbean. Harper Collins, London

Lincoln-Smith MP (1988) Effects of observer swimming speed on sample counts of temperate rocky reef fish assemblages. Mar Ecol Prog Ser 43:223-231

McClanahan TR (1994) Kenyan coral reef lagoon fish: effects of fishing, substrate complexity, and sea urchins. Coral Reefs 13:231-241

McClanahan TR (1998) Predation and the distribution and abundance of tropical sea urchin populations. J Exp Mar Biol Ecol 221:231-255

McClanahan TR, Arthur R (2001) The effect of marine reserves and habitat on populations of East African coral reef fishes. Ecol Appl 11:559-569

McClanahan TR, Graham NAJ (2005) Recovery trajectories of coral reef fish assemblages within Kenyan marine protected areas. Mar Ecol Prog Ser 294:241-248

McClanahan TR, Mangi S (2001) The effect of closed area and beach seine exclusion on coral reef fish catches. Fish Manag Ecol 8:107-121 
Planes S, Levefre A, Legendre P, Galzin R (1993) Spatio-temporal variability in fish recruitment to a coral reef (Moorea, French Polynesia). Coral Reefs 12:105-113

Rahel FJ (1990) The hierarchical nature of community persistence: a problem of scale. Am Nat 136:328-344

Rahel FJ, Lyons JD, Cochran PA (1984) Stochastic or deterministic regulation of assemblage structure? It may depend on how the assemblage is defined. Am Nat 124:583-589

Russ GR, Alcala AC (2004) Marine reserves: long-term protection is required for full recovery of predatory fish populations. Oecologia 138:622-627

Sale PF, Douglas WA (1984) Temporal variability in the community structure of fish on coral patch reefs and the relation of community structure to reef structure. Ecology 56: $1342-1355$

Sale PF, Dybdahl R (1975) Determinants of community structure for coral reef fishes in an experimental habitat. Ecology 56:1343-1355

Sale PF, Steel WJ (1989) Temporal variability in patterns of association among fish species on coral patch reefs. Mar Ecol Prog Ser 51:35-47

Sale PF, Doherty PJ, Eckert GJ, Douglas WA, Ferrell DJ (1984) Large scale spatial and temporal variation in recruitment to fish populations on coral reefs. Oecologia 64:191-198

Samoilys M, Carlos G (2000) Determining methods of underwater visual census for estimating the abundance of coral reef fishes. Environ Biol Fishes 57:289-304

Stewart-Oaten A, Murdoch WW, Walde SJ (1995) Estimation of temporal variability in populations. Am Nat 146: 519-535

Editorial responsibility: Otto Kinne (Editor-in-Chief), Oldendorf/Luhe, Germany
Syms C, Jones GP (2000) Disturbance, habitat structure, and the dynamics of a coral-reef fish community. Ecology 81: 2714-2729

Tessier E, Chabanet P, Pothin K, Soria M, Lesserre G (2005) Visual censuses of tropical fish aggregations on artificial reefs: slate versus video recording techniques. J Exp Mar Biol Ecol 315:17-30

Thompson AA, Mapstone BD (2002) Inta-versus inter-annual variation in counts of reef fishes and interpretations of long-term monitoring studies. Mar Ecol Prog Ser 232: 247-257

Williams DM (1983) Daily, monthly, and yearly variability in recruitment of a guild of coral reef fishes. Mar Ecol Prog Ser 10:231-237

Williams ID, Walsh WJ, Tissot BN, Hallacher LE (2006) Impact of observers' experience level on counts of fishes in underwater visual surveys. Mar Ecol Prog Ser 310: 185-191

Willis TJ (2001) Visual census methods underestimate density and diversity of cryptic reef fishes. J Fish Biol 59: $1408-1411$

Willis T, Badalamenti F, Milazzo M (2006) Diel variability in counts of reef fishes and its implications for monitoring. J Exp Mar Bio Ecol 331:108-120

Wilson SK, Graham NAJ, Pratchett MS, Jones GP, Polunin NVC (2006) Multiple disturbances and the global degradation of coral reefs: are reef fishes at risk or resilient? Glob Change Biol 12:2220-2234

Zeller DC (1997) Home range and activity patterns of the coral trout Plectropomus leopardus (Serranidae). Mar Ecol Prog Ser 154:65-77

Submitted: November 4, 2005; Accepted: November 30, 2006 Proofs received from author(s): May 24, 2007 